\title{
UNION INFLUENCE IN POST-SOCIALIST EUROPE
}

\author{
RICHARD CROUCHER AND MARIAN RIZOV*
}

\begin{abstract}
Examining enterprise-level union influence in post-socialist countries, the authors hypothesize that calculative human resource management (HRM) is more strongly associated with low levels of union influence than collaborative HRM. Using the United Kingdom as a benchmark, they find that in the countries under study, calculative HRM is indeed more damaging to union influence than collaborative, although to a much lesser extent than in the United Kingdom. They also find that union influence corresponds to enterprise union density and is most apparent when the business cycle is unfavorable; they explain their findings by reference to East European members' continued attachment to unionism for nonbargaining reasons.
\end{abstract}

\section{W} e examine enterprise-level union influence in post-socialist countries (PSCs), and seek to discover its antecedents. Research on union influence at the enterprise level in post-socialist Europe is sparse, despite the fact that unions retain highly decentralized structures and funds. Yet influential unions are more likely to provide a solid basis for the European Union (EU) social dialogue processes; conversely, unions at this level that are not influential may eventually erode the European model. We find that union density, collaborative HRM, and the business cycle are all significant antecedents of union influence and that previous national-level estimates are a useful but imprecise guide to enterprise-level influence.

\section{Management and Unions before 1989}

Many researchers suggest (Vos 2006; Knell and Srholec 2007; Meardi 2007a, 2007b; Woolfson 2007; Trif 2008) that soviet management legacies remain influential in PSCs. Labor management, like unions, had a major political role within the socialist system (Tung and Havlovic 1996), and this emphasized the need to build socialism through efficient production (Kornai 1992). Unions were part of enterprise management. Little importance was accorded to the personnel function, which consisted of selection, discipline and, to some extent, training (Tung and Havlovic 1996). Although the personnel function is now widely referred to as $H R M$, it often has no strategic

\footnotetext{
*Richard Croucher is Professor of Comparative Employment Relations and Director of Research at Middlesex University Business School. Marian Rizov is Reader in Economics at Middlesex University Business School.

Cranet data are the property of the Cranet network, coordinated by Cranfield School of Management, Cranfield University in the UK. Data are administered by the network coordinator located there.
} 
role. In many PSCs much of this management system remains (Brewster, Mayrhofer, and Morley 2005).

Trade unionism is still marked by the communist experience (Soulsby and Clark 2007; Noelke and Vliegenthart 2009); union roles may in some countries still be filled by managers (Trif 2008). Pre-1989 union functions were essentially corporatist: to integrate and motivate workers. Unions also had major political roles as transmission belts for Communist policy, which currently creates legitimacy problems (Meardi 2006). Although they acquired minor representational functions under communism (Kornai 1992), they also had large legal departments which remain important in many unions (Trif 2005; Meardi 2006). Membership was compulsory, and unions stood largely aloof from workers' informal bargaining over piece rates (Haraszti 1978). They had important welfare functions and allocated resources to providing workers with holidays for themselves and their families, housing, and money when they had particular needs. Workers were encouraged to identify with the labor collective, an ideological construct acquiring concrete reality through collective workplace events and the union itself. Current union membership can reflect continuing identification with these functions even though union resources in the welfare area are much diminished and no longer include housing (Trif 2005). The social movement unionism that emerged in some countries before 1989 was superimposed on this situation.

\section{Trade Unions since 1989}

Before 1989 union influence was simply exercised, if at all, as part of the management function. When a market system began to be implemented, this disappeared: management was then influenced by their perceptions of unions' capacity to mobilize their members. We term this direct union influence. Unions, however, might also retain some influence through their capacity to shape members' views and hence their levels of commitment to management initiatives. Their legal watchdog role may also allow pressure to be put on management. We call these forms indirect influence because they are less reliant on mobilization capacity. The basis for this is in members' perceptions of union functions. Indirect influence is likely to be stronger in the PSCs than elsewhere, where union bargaining functions are more central. In short, unions may have either direct or indirect influence; and management may use the latter to shape a form of unionism that presents little challenge to management prerogative.

PSCs have been strongly exposed to global markets and financial institutions, bringing mass privatization, unemployment, and a shift away from full-time permanent employment (Bohle and Greskovits 2007; Baranowska and Gebel 2008; Psychogios, Szamosi, and Wood 2010; Williams 2010). Workers are therefore invariably in weak positions, except where skill shortages exist, and this weakness is reflected in unions' low mobilization capacity (Psychogios et al. 2010). Their direct influence is therefore weak. 
Initially, in 1989 and 1990, unions were seen as a possible focus for social unrest, likely to defend privileges accorded the working class under communism. In that brief period, they were brought into tripartite discussion (Casale 1999). Yet governments gradually set tripartism aside, giving way to a long period of neoliberal-inspired legislation and employer hostility. The international financial institutions insisted on labor market reform and explicitly linked it to a need to reduce union influence (Giacobbe-Miller, Miller, and Victorov 1998). ${ }^{1}$ By the mid-2000s, discussion centered on unions' incapacity to act as credible social partners within the EU (Meardi 2006).

PSCs show considerable diversity, but they share common features that corrode union membership and influence. EU legislation and influence have had liberalizing effects (Woolfson 2007; Meardi 2007b), although some suggest that EU influence simply reproduces prior levels of joint regulation (Trif 2008). Wage bargaining is often decentralized and in some countries may be conducted by employee representatives instead of unions; works councils, where they exist, have only weak consultation powers, and industrial action is rare (ILO 2000; Funk and Lesch 2004). In the one country with a relatively strong union movement, Slovenia, tripartism has operated successfully since the mid-1990s (Frail 2009). Elsewhere, experts judge unions to be much weaker (Mailand and Due 2004; to compare this judgment with the ILO view, see Dimitrova and Vilrokx 2005). National-level tripartism is much less effective than in Western Europe because it was instituted through a top-down process (Mailand and Due 2004). Ost (2000) describes it as "illusory corporatism": driven by new elites, it serves their liberalizing purposes. While these arrangements give formal voice to unions, Ost argues that labor is complicit in a process that diminishes its own influence. Outside sectors protected from competition, many unions are too weak to insist on observance of any agreement, much less to bargain supplements to national agreements as legally permitted in Romania (Trif 2005; EFILWC 2009). Enterprise agreements on occasion specify worse terms and conditions than legal minima (Bernaciak, Duman, and Scepanovic 2010).

Most national union density estimates fall between $16 \%$ and $22 \%$ (for Bulgaria, Czech Republic, Estonia, Hungary, Slovakia, and Slovenia) and, at either extreme, Slovenia at $44 \%$ and Estonia at $7.6 \%$ (EIRO 2010). Slovenian strength and Baltic weakness are reflected in other findings in terms of union wider capacities (Buchen 2007; Stockhammer and Onaran 2009), their ability to conduct social dialogue (Mailand and Due 2004), to carry out extrajudicial action (Welz and Kauppinen 2005), and to defend women members (Pollert 2005).

\footnotetext{
'In several studies the elimination of labor hoarding is identified as an important (necessary) component of enterprise restructuring policies promoted by international financial institutions. Another important (sufficient) component is new investment in productive assets rather than using funds for enterprise survival. The success of restructuring policies is conditional on eliminating soft budget constraints (Konings, Rizov, and Vandenbussche 2003; Rizov 2005), directly linked to abandoning the state's role in ensuring full employment.
} 
After 1990 unions made efforts to become more mobilizing and bargaining bodies (Gennard 2007; Croucher and Cotton 2009). Yet extensive qualitative functional change has proved difficult, and because of mixed verdicts from experts, it remains unclear how far their efforts have succeeded. Thirkell, Petkov, and Vickerstaff (1998) cited MSzOSz in Hungary and CITUB in Bulgaria as reformed federations that were stronger than they had been before 1999. Gennard (2007), analyzing print unions' positions, passed a more qualified judgment. Crowley (2004) went further, arguing that many unions remained unreformed, which helped to explain labor quiescence, while King (2007) characterized Central European unions as highly ineffective.

Unions at the enterprise level may have certain limited resources to buttress their influence. First, high union density may provide representative legitimacy and underpin some prospect of direct influence (Vernon 2006). Second, management can concede union influence to help them effect change (Crowley 2004; Croucher 2010). This may be buttressed by the legal watchdog role, union welfare functions and continued identification with it as an institutional embodiment of the "labor collective." The legal watchdog role acquires particular significance where relatively strong worker protection remains in place, as in some countries (Trif 2005). Finally, they may exercise indirect influence on management by diffusing discontent on the shop floor (Gomez-Mejia and Welbourne 1994).

\section{Forms of HRM}

$H R M$ is used by Western companies, to some extent by private companies, and even occasionally in the state sector (Brewster et al. 2005). Forms of HRM all emphasize alignment of employer and employee interests, but vary considerably. Gooderham, Nordhaug, and Ringdal $(1999,2006)$ identified two forms that broadly reflect, on the one hand, American and, on the other, West European approaches: calculative and collaborative HRM. Calculative HRM treats labor as an abstract factor of production, stressing individualized reward, appraisal, and employee development monitoring systems. Collaborative approaches have a more humanistic orientation, viewing employees as active partners, and emphasizing intensive downward communication with employees at all levels (Gooderham et al. 1999). Collaborative approaches are part of relational policies (Gospel and Pendleton 2005) and, as Gooderham et al. 1999 acknowledge, have much in common with soft HRM (Storey 2001). The Gooderham et al. typology does not reflect a full set of soft HRM practices; the soft characterization explicitly includes a relatively positive attitude to unionization.

We adopt this conceptualization because it captures two paradigmatic sets of practices. We prefer the Gooderham et al. conceptualization to the vaguer, normative or prescriptive hard and soft HRM dichotomy (see, for example, Storey 2001). Also unlike the hard and soft conceptualization, the 
Gooderham et al. typology has the advantage that it treats unions as exogenous, and there is therefore no problem of endogeneity in measurement.

Calculative HRM is the form usually adopted by private companies in the PSCs. It allows and reflects, as the concept's authors explain, higher levels of management choice. Gooderham et al. (1999) argue that calculative HRM is strongly linked to managements' wish to increase their autonomy and scope for initiative. Individualized pay systems have been adopted and promoted to other companies by multinational corporations (MNCs). MNCs operate in the PSCs (EFILWC 2009). Gooderham et al. (1999) suggest that calculative HRM is closely associated with reduced union influence in Western Europe; unions resist it, but they don't resist the collaborative form. This is because it is based on a negative view of collective representation and emphasizes individual assessment and reward. This may also have an effect in the PSCs, both by concrete results, such as reducing the material significance of collective bargaining, and also in a less direct way by sending the message to employees that collective institutions are unwelcome.

In the PSCs, however, both union functions and members' perceptions of what these should be are fundamentally different from those in much of the rest of the world. In other societies, and especially in the liberal market economies, we would not expect welfare and affective considerations to have similar relevance. In our analysis, therefore, we include the United Kingdom as a benchmark, since we expect calculative HRM to have a marked negative effect on union influence there, as Gooderham et al.'s theory predicts.

We therefore propose the hypothesis: In PSCs, calculative HRM is associated with lower union influence than the collaborative form, but less so than in the United Kingdom benchmark.

\section{Data and Variables}

Our data derive from the 2003-4 round of Cranet, an international enterprise-level survey of HRM practices conducted at regular intervals since 1989 across a large number of countries by a well-established international research network. Cranet is by far the most comprehensive international survey of HR policies and practices at the organizational level. The survey encompasses all areas of economic activity, but it excludes firms employing fewer than 100 staff and targets organizations employing more than 200. Respondent firms are chosen to reflect the broad industrial composition by employment within each country surveyed. It covers private and public organizations in 22 European countries, as well as some dozen others (Brewster et al. 2005). It is directed at HR managers or, in the absence of an HR manager, the senior manager responsible for HR issues, and it uses predominantly closed questions on policies and practices rather than attitudes. This ensures unambiguous responses on actual policies and practices. The questions are agreed on by members of the network, translated into the appropriate language, and then translated back into English to identify any 
problems with international meaning and comparability. In the countries involved in our sample, the survey was administered by mail. Data collection in these countries poses considerable and specific difficulties (Drzewiecka 2007). There is a tradition of secrecy among managers (Danilovich and Croucher 2011), which can be partially overcome by using local researchers in each country. Full technical details are available in Brewster et al. (2005).

We use data from all the PSCs for which data are available (Bulgaria, Czech Republic, Estonia, Hungary, Slovakia, and Slovenia) and, as our liberal market economy benchmark, from the United Kingdom. These countries exhibit diverse institutional settings, and they include a Balkan country (Bulgaria) as well as a Baltic one (Estonia) and a group of significant Central European economies. All are members of the EU. We also include in our sample firms that are part of multinational companies (MNCs). The incidence of MNCs in our sample exhibits a pattern consistent with aggregate statistics on MNCs' presence in the region (WIIW 2003).

Our main dependent variable is union influence at the firm level (TUIN), measured as a dichotomous variable with a value of 1 when managers reported some union influence and 0 otherwise. We asked managers if union influence has increased, decreased, or remained the same over the previous three years, or if no union influence existed. We classify the first three categories as "some influence" and the last as "no influence." We believe that treating the question in this way provided reliable information; we experimentally redefined the variable by excluding the decreased category, but the results, available on request, remained qualitatively the same. Using these data, it is impossible to distinguish between direct and indirect influence, as we do on the theoretical level. We also analyze unions' presence $(T U P R)$ in firms and measure this on a scale with six categories according to the share of firm employees in union membership. ${ }^{2}$ Verma, Kochan, and Wood (2002) argue that union density is the best overall indicator of union influence. Thus, by using both TUIN and TUPR, we believe that we achieve the most reliable indication of whether union influence exists. Table $1 \mathrm{dem}-$ onstrates the high correlations (Pearson correlation coefficients) of TUIN and TUPR both by country and for the total PSCs and United Kingdom samples.

In extended regressions, we use two measures of the two major types of labor management practices as formulated by Gooderham et al. (1998, 1999), calculative HRM (CALC) and collaborative HRM (COLL) as control variables. We augment the collaborative HRM measure with group practice components following Rizov and Croucher (2009). The calculative HRM measure is also augmented by our use of a compulsory redundancy component. We note that in this analysis we use CALC and COLL to control for the impact of HRM practices on union influence, rather than study the practices themselves in depth. Composite scales are used for CALC and COLL,

\footnotetext{
${ }^{2}$ The six categories are defired as follows: category 0 corresponds to $0 \%$ share, 1 to $1 \%-10 \%$ share, 2 to $11 \%-25 \%$ share, 3 to $26 \%-50 \%$ share, 4 to $51 \%-75 \%$ share, and 5 to $76 \%-100 \%$ share.
} 
Table 1. Correlation of Union Influence (TUIN) and Presence (TUPR) in the PSCs and the United Kingdom

\begin{tabular}{lcccccccc}
\hline & & & \multicolumn{4}{c}{ Czech } & Total \\
& Bulgaria & Hungary & Estonia & Slovenia & Slovakia & Republic & PSCs & U.K. \\
\hline Correlation coefficient & 0.64 & 0.85 & 0.66 & 0.68 & 0.80 & 0.70 & 0.76 & 0.70 \\
\hline
\end{tabular}

Note: All (Pearson) correlation coefficients are significant at the $p=0.001$ level.

comprising indicators of HRM practices of 15 and 13 components, respectively. In identifying the components of each scale we pay attention to the contexts of both the PSCs and the United Kingdom.

The CALC scale is a composite of indicators for base and variable pay that are directly related to performance for all employee categories, regular formal appraisal for managers, professionals, clerical, and manual workers, use of formal appraisal in informing career and pay decisions as well as use of compulsory redundancies. We were unable to reproduce all of the original Gooderham et al. calculative scale because the two items on monitoring training effectiveness were not used in the 2004 questionnaire; however, it seems likely that the use of the appraisals questions may to some extent mitigate this issue.

The COLL scale comprises indicators for formal strategy briefings of all categories of employees and the presence of a written mission and corporate values statement, extended by measures for minority inclusion, career development through team work, the presence of mechanisms for two-way communication at team level, and the existence of a works council or joint consultative committee.

Each HRM indicator is an ordinal categorical variable. We apply Mokken's nonparametric scaling model (Mokken and Lewis 1982) to compute our synthetic HRM indices as did Gooderham et al. (1999). The unweighted sum of item scores must be monotonously related to the latent true scores, as demonstrated by Sjitsma, Debets, and Molenaar (1990). This implies that Mokken's model provides only estimates of the scale scores at ordinal level. The primary scaling criterion is Loevinger's H-coefficient of homogeneity. A set of items constitutes a scale if the aggregate has an H-value exceeding 0.30 ; values above 0.50 indicate strong scales. The consistency of the scales is also verified by Cronbach's Alpha, which increases as the intercorrelations among scale items increase and is thus an internal consistency estimate of the scale's reliability. Because intercorrelations among test items are maximized, when all items measure the same construct, Cronbach's Alpha is taken as indirectly indicating the degree to which a set of items measures a single unidimensional latent construct. Alpha values above 0.70 indicate a strong scale. Details of the items included in the scales, results of the scaling, and our reliability analysis are reported in the Appendix, Tables A.1a and A.1b for the PSC and U.K. samples, respectively.

In Table 2 we report for all PSCs in our sample by country summary statistics on union influence, MNC presence (measured as a share of surveyed 
Table 2. Union Influence, Ownership, and HRM Practices in the PSCs

\begin{tabular}{lccccc}
\hline & TUIN & MNC & PRIV & CALC & COLL \\
\hline Bulgaria & $0.58(0.49)$ & $0.17(0.38)$ & $0.64(0.48)$ & $0.56(0.30)$ & $0.47(0.31)$ \\
Czech Republic & $0.82(0.39)$ & $0.22(0.42)$ & $0.86(0.35)$ & $0.74(0.26)$ & $0.78(0.25)$ \\
Estonia & $0.38(0.49)$ & $0.15(0.35)$ & $0.62(0.49)$ & $0.44(0.29)$ & $0.68(0.27)$ \\
Hungary & $0.60(0.49)$ & $0.27(0.44)$ & $0.62(0.49)$ & $0.50(0.30)$ & $0.61(0.32)$ \\
Slovakia & $0.55(0.50)$ & $0.20(0.40)$ & $0.82(0.39)$ & $0.56(0.29)$ & $0.58(0.29)$ \\
Slovenia & $0.91(0.29)$ & $0.12(0.30)$ & $0.63(0.48)$ & $0.70(0.27)$ & $0.67(0.27)$ \\
\hline
\end{tabular}

Notes: Means and standard deviations (in parentheses) are reported. CALC and COLL indices are normalized to the interval $[0,1]$. Abbreviations: TUIN, union influence; MNC, multinational firm; PRIV, private firm; CALC, calculative HRM; COLL, collaborative HRM.

firms), the importance of private ownership, and the prevalence of calculative and collaborative HRM practices. The summary statistics confirm that our data approximate to the empirical facts established by other studies using different data sources.

Following the conceptual frameworks of Gooderham et al. (1998, 1999) and of Rizov and Croucher (2009), we control in our regression analysis for firm characteristics affecting union influence and the prevalence of HRM practices. These are log of firm size (Firm size), log of firm age (Firm age), and a dummy variable indicating private ownership (Private firm). In all regressions a control dummy variable for foreign ownership and management in large organizations is also included (Multinational firm). Market conditions are controlled for by a three-step ordinal scale indicating whether the firm's market is declining, steady, or growing (Business cycle). Industrial sector information, a set of industry dummy variables (Primary industries, Manufacturing, and Construction), is included in extended regression specifications (Services is the reference category). Finally, we capture cross-country differences with country dummy variables used in extended regression specifications to control for variations in institutional settings. Summary statistics and short definitions of all regression variables are reported in Table 3. Correlation matrices for selected regression variables are presented in the online version of the paper (Tables A.2a and A.2b for PSCs and U.K. samples, respectively) on http://eprints.mdx.ac.uk/8038/. The low correlations between regression variables indicate no endogeneity problems.

\section{Econometric Analysis}

\section{Determinants of Union Influence}

Given that the dependent variable of main interest (union influence) is dichotomous we first estimate relationships by a probit regression and report the estimation results (marginal effects) in Table $4 \mathrm{a}$ for the PSCs and in Table 4b for the United Kingdom. Following Gooderham et al. (1999) and Rizov and Croucher (2009), we start with a base specification in which the explanatory variables are simply the main firm characteristics. In a second extended specification we add information on private and foreign ownership. 
Table 3. Summary Statistics

\begin{tabular}{|c|c|c|c|}
\hline Variable & Definition & PSCS & U.K. \\
\hline TUIN & Union influence dummy variable equal to 1 and 0 otherwise & $\begin{array}{c}0.63 \\
(0.37)\end{array}$ & $\begin{array}{c}0.64 \\
(0.48)\end{array}$ \\
\hline TUPR & Union presence scale ranging between 0 and 5 (low-high) & $\begin{array}{c}2.13 \\
(1.26)\end{array}$ & $\begin{array}{c}1.90 \\
(1.67)\end{array}$ \\
\hline CALC & Calculative HRM composite scale ranging between 0 and 15 & $\begin{array}{c}8.86 \\
(2.92)\end{array}$ & $\begin{array}{c}7.94 \\
(3.27)\end{array}$ \\
\hline COLL & Collaborative HRM composite scale ranging between 0 and 13 & $\begin{array}{c}7.21 \\
(2.95)\end{array}$ & $\begin{array}{c}8.38 \\
(2.63)\end{array}$ \\
\hline Firm size & Log of firm size (tolal labor force) & $\begin{array}{c}5.78 \\
(1.23)\end{array}$ & $\begin{array}{c}6.46 \\
(1.28)\end{array}$ \\
\hline Firm age & Log of firm age (years) & $\begin{array}{c}2.83 \\
(1.03)\end{array}$ & $\begin{array}{c}3.54 \\
(1.13)\end{array}$ \\
\hline $\begin{array}{l}\text { Multinational } \\
\text { firm (MNC) }\end{array}$ & $\begin{array}{l}\text { Dummy variable which is } 1 \text { if the firm is a foreign multinational } \\
\text { and } 0 \text { otherwise }\end{array}$ & $\begin{array}{c}0.16 \\
(0.37)\end{array}$ & $\begin{array}{c}0.14 \\
(0.35)\end{array}$ \\
\hline Private firm & Dummy variable which is 1 if the firm is private and 0 otherwise & $\begin{array}{c}0.70 \\
(0.46)\end{array}$ & $\begin{array}{c}0.70 \\
(0.46)\end{array}$ \\
\hline Business cycle & $\begin{array}{l}\text { Scale of business cycle conditions ranging between } 1 \text { and } 3 \\
\text { (recession-expansion) }\end{array}$ & $\begin{array}{c}2.38 \\
(0.68)\end{array}$ & $\begin{array}{c}2.28 \\
(0.75)\end{array}$ \\
\hline Primary industries & $\begin{array}{l}\text { Dummy variable which is } 1 \text { for primary industries and } 0 \text { other- } \\
\text { wise }\end{array}$ & $\begin{array}{c}0.10 \\
(0.30)\end{array}$ & $\begin{array}{c}0.03 \\
(0.18)\end{array}$ \\
\hline Manufacturing & Dummy variable which is 1 for manufacturing and 0 otherwise & $\begin{array}{c}0.23 \\
(0.42)\end{array}$ & $\begin{array}{c}0.31 \\
(0.46)\end{array}$ \\
\hline Construction & Dummy variable which is 1 for construction and 0 otherwise & $\begin{array}{c}0.04 \\
(0.19)\end{array}$ & $\begin{array}{c}0.03 \\
(0.18)\end{array}$ \\
\hline Services & $\begin{array}{l}\text { Dummy variable which is } 1 \text { for services retail and wholesales } \\
\text { and } 0 \text { otherwise }\end{array}$ & $\begin{array}{c}0.63 \\
(0.84)\end{array}$ & $\begin{array}{c}0.51 \\
(0.50)\end{array}$ \\
\hline Bulgaria & $\begin{array}{l}\text { Dummy variable which is } 1 \text { if the firm is in Bulgaria and } 0 \text { oth- } \\
\text { erwise }\end{array}$ & $\begin{array}{c}0.18 \\
(0.38)\end{array}$ & \\
\hline Czech Republic & $\begin{array}{l}\text { Dummy variable which is } 1 \text { if the firm is in Czech Republic and } \\
0 \text { otherwise }\end{array}$ & $\begin{array}{c}0.08 \\
(0.28)\end{array}$ & \\
\hline Hungary & $\begin{array}{l}\text { Dummy variable which is } 1 \text { if the firm is in Hungary and } 0 \text { oth- } \\
\text { erwise }\end{array}$ & $\begin{array}{c}0.11 \\
(0.32)\end{array}$ & \\
\hline Estonia & $\begin{array}{l}\text { Dummy variable which is } 1 \text { if the firm is in Estonia and } 0 \text { other- } \\
\text { wise }\end{array}$ & $\begin{array}{c}0.14 \\
(0.34)\end{array}$ & \\
\hline Slovakia & $\begin{array}{l}\text { Dummy variable which is } 1 \text { if the firm is in Slovakia and } 0 \text { oth- } \\
\text { erwise }\end{array}$ & $\begin{array}{c}0.30 \\
(0.46)\end{array}$ & \\
\hline Slovenia & $\begin{array}{l}\text { Dummy variable which is } 1 \text { if the firm is in Slovenia and } 0 \text { oth- } \\
\text { erwise }\end{array}$ & $\begin{array}{c}0.19 \\
(0.39)\end{array}$ & \\
\hline
\end{tabular}

Note: Means and standard deviations (in parentheses) are reported. Number of observations used in calculating summary statistics is 747 for PSC sample and 800 for the United Kingdom.

Next, the specification (in Table 4a) also includes a set of PSCs dummy variables that capture variations in institutional specificities across countries, with reference to the Czech Republic. We further extend the specification with a measure of market conditions and subsequently add a set of industry dummy variables with aggregate services as the reference category. The stability of coefficients in all regressions when introducing stepwise explanatory variables indicates no endogeneity problems. ${ }^{3}$ Nevertheless, we are cautious in drawing conclusions regarding causality and interpret our results simply

\footnotetext{
${ }^{3}$ In all regressions we have included variables describing key respondent characteristics to control for a possible measurement error due to self-reporting. The individual-level control variables are gender, education, and years of service in the organization, and we assume that they are not correlated with the
} 
Table 4a. Determinants of Union Influence (TUIN) in the PSCs (probit estimator)

\begin{tabular}{|c|c|c|c|c|c|c|}
\hline \multirow[b]{2}{*}{ Variables } & \multicolumn{6}{|c|}{ Models } \\
\hline & i) & $(2)$ & (3) & (4) & (5) & (6) \\
\hline \multirow[t]{2}{*}{ Firm size } & $0.165^{* * *}$ & $0.175 * * *$ & $0.166 * * *$ & $0.170 * * *$ & $0.153 * * *$ & $0.149 * * *$ \\
\hline & $(0.018)$ & $(0.018)$ & $(0.020)$ & $(0.020)$ & $(0.020)$ & $(0.021)$ \\
\hline \multirow[t]{2}{*}{ Firm age } & $0.094 * * *$ & $0.077 * * *$ & $0.062 * * *$ & $0.056 * * *$ & $0.056 * * *$ & $0.055^{* * * *}$ \\
\hline & $(0.019)$ & $(0.020)$ & $(0.021)$ & $(0.021)$ & $(0.021)$ & $(0.021)$ \\
\hline \multirow[t]{2}{*}{ Multinational firm } & & $-0.166 * * *$ & $-0.155^{* * *}$ & $-0.145^{* * *}$ & $-0.161 * * *$ & $-0.164 * * *$ \\
\hline & & $(0.054)$ & $(0.056)$ & $(0.056)$ & $(0.057)$ & $(0.058)$ \\
\hline \multirow[t]{2}{*}{ Private firm } & & $-0.152 * * *$ & $-0.179 * * *$ & $-0.162 * * *$ & $-0.170^{* * *}$ & $-0.164 * * *$ \\
\hline & & $(0.042)$ & $(0.042)$ & $(0.043)$ & $(0.046)$ & $(0.046)$ \\
\hline \multirow[t]{2}{*}{ Bulgaria } & & & $-0.331 * * *$ & $-0.320^{* * *}$ & $-0.330^{* * * k}$ & $-0.310^{* * * *}$ \\
\hline & & & $(0.086)$ & $(0.087)$ & $(0.089)$ & $(0.092)$ \\
\hline \multirow[t]{2}{*}{ Hungary } & & & $-0.201 * *$ & $-0.194 * *$ & $-0.195 * *$ & $-0.196^{* *}$ \\
\hline & & & $(0.097)$ & $(0.097)$ & $(0.099)$ & $(0.099)$ \\
\hline \multirow[t]{2}{*}{ Estonia } & & & $-0.379 * * *$ & $-0.374 * * *$ & $-0.369 * * *$ & $-0.399 * * *$ \\
\hline & & & $(0.088)$ & $(0.088)$ & $(0.090)$ & $(0.089)$ \\
\hline \multirow[t]{2}{*}{ Slovenia } & & & $0.153^{*}$ & $0.158^{*}$ & $0.160^{*}$ & $0.143^{*}$ \\
\hline & & & $(0.077)$ & $(0.077)$ & $(0.078)$ & $(0.079)$ \\
\hline \multirow[t]{2}{*}{ Slovakia } & & & -0.093 & -0.086 & -0.094 & -0.085 \\
\hline & & & $(0.082)$ & $(0.082)$ & $(0.083)$ & $(0.083)$ \\
\hline \multirow[t]{2}{*}{ Business cycle } & & & & $-0.088^{* * *}$ & $-0.070^{* * *}$ & $-0.074 * *$ \\
\hline & & & & $(0.030)$ & $(0.030)$ & $(0.031)$ \\
\hline \multirow[t]{2}{*}{ Primary industries } & & & & & $0.185^{* * * *}$ & $0.176^{* * * *}$ \\
\hline & & & & & $(0.052)$ & $(0.053)$ \\
\hline \multirow[t]{2}{*}{ Manufacturing } & & & & & $0.113 * * *$ & $0.112 * * *$ \\
\hline & & & & & $(0.044)$ & $(0.044)$ \\
\hline \multirow[t]{2}{*}{ Construction } & & & & & 0.088 & 0.080 \\
\hline & & & & & $(0.082)$ & $(0.083)$ \\
\hline \multirow[t]{2}{*}{ COLL } & & & & & & $0.103^{* *}$ \\
\hline & & & & & & $(0.050)$ \\
\hline \multirow[t]{2}{*}{ CALC } & & & & & & $-0.116^{*}$ \\
\hline & & & & & & $(0.067)$ \\
\hline Pseudo R_squared & 0.21 & 0.28 & 0.40 & 0.41 & 0.46 & 0.49 \\
\hline Number observations & 747 & 747 & 747 & 747 & 747 & 747 \\
\hline
\end{tabular}

Notes: Coefficients reported represent marginal effects. Reference country is Czech Republic, and reference industry is Services. Level of significance of estimated coefficients is indicated as follows: $1 \% * * *$, $5 \% * *, 10 \% *$. COLL and CALC HRM scales are in logs.

as evidence of correlations between variables. We conceptualize the results as showing a mutually determined relationship; since management clearly has control, its policies are of great significance, but union policies and practices are also likely to have some impact on the relationships.

Comparing overall results for the United Kingdom and the PSCs, the effects' signs are the same, except for the Multinational firm variable; however, for some variables the level of significance is higher and the coefficients' magnitudes appear larger for the PSCs sample. ${ }^{4}$ For the PSC sample, firm size and age have positive and statistically significant impacts on union

firm-level variables. Individual-level controls were neither individually nor jointly statistically significant in any regression, and therefore their coefficients were not reported.

${ }^{4}$ We test for differences in coefficients for the PSC and U.K. samples using Wald tests and find that jointly for all coefficients the differences are significant at $10 \%$ level or better for the majority of the models. 
Table 4b. Determinants of Union Influence (TUIN) in the United Kingdom (probit estimator)

\begin{tabular}{|c|c|c|c|c|c|}
\hline \multirow[b]{2}{*}{ Variables } & \multicolumn{5}{|c|}{ Models } \\
\hline & (1) & $(2)$ & (3) & (4) & (5) \\
\hline Firm size & $\begin{array}{l}0.120^{* * *} \\
(0.015)\end{array}$ & $\begin{array}{l}0.117 * * * \\
(0.016)\end{array}$ & $\begin{array}{l}0.118^{* * *} \\
(0.016)\end{array}$ & $\begin{array}{l}0.118^{* * *} \\
(0.016)\end{array}$ & $\begin{array}{l}0.116^{* * *} \\
(0.016)\end{array}$ \\
\hline Firm age & $\begin{array}{c}0.033^{* *} \\
(0.016)\end{array}$ & $\begin{array}{c}0.031 * * \\
(0.016)\end{array}$ & $\begin{array}{l}0.031 * * \\
(0.016)\end{array}$ & $\begin{array}{c}0.026 \\
(0.016)\end{array}$ & $\begin{array}{c}0.020 \\
(0.017)\end{array}$ \\
\hline Multinational firm & & $\begin{array}{c}0.063 \\
(0.046)\end{array}$ & $\begin{array}{c}0.059 \\
(0.047)\end{array}$ & $\begin{array}{c}0.043 \\
(0.048)\end{array}$ & $\begin{array}{c}0.055 \\
(0.047)\end{array}$ \\
\hline Private firm & & $\begin{array}{l}-0.275^{* * * *} \\
(0.034)\end{array}$ & $\begin{array}{l}-0.285^{* * *} \\
(0.034)\end{array}$ & $\begin{array}{l}-0.346^{* * *} \\
(0.033)\end{array}$ & $\begin{array}{c}-0.285^{* *} \\
(0.038)\end{array}$ \\
\hline Business cycle & & & $\begin{array}{l}-0.033 \\
(0.023)\end{array}$ & $\begin{array}{l}-0.026 \\
(0.024)\end{array}$ & $\begin{array}{c}-0.024 \\
(0.024)\end{array}$ \\
\hline Primary industries & & & & $\begin{array}{l}0.202 * * * \\
(0.064)\end{array}$ & $\begin{array}{l}0.199 * * * * \\
(0.060)\end{array}$ \\
\hline Manufacturing & & & & $\begin{array}{l}0.243^{* * * *} \\
(0.036)\end{array}$ & $\begin{array}{l}0.228 * * * \\
(0.036)\end{array}$ \\
\hline Construction & & & & $\begin{array}{c}0.082 \\
(0.087)\end{array}$ & $\begin{array}{c}0.082 \\
(0.082)\end{array}$ \\
\hline COLL & & & & & $\begin{array}{l}0.243^{* * * *} \\
(0.050)\end{array}$ \\
\hline CALC & & & & & $\begin{array}{l}-0.306^{* * *} \\
(0.054)\end{array}$ \\
\hline Pseudo R_squared & 0.15 & 0.21 & 0.21 & 0.26 & 0.32 \\
\hline Number observations & 800 & 800 & 800 & 800 & 800 \\
\hline
\end{tabular}

Notes: Coefficients reported represent marginal effects. Reference industry is Services. Level of significance of estimated coefficients is indicated as follows: $1 \%^{* * *}, 5 \%^{* *}, 10 \%^{*}$. COLL and CALC HRM scales are in logs.

influence. Union influence, however, is significantly statistically weaker in foreign-owned and private firms. Using the Czech Republic as the reference country, firms in Bulgaria, Hungary, and Estonia are characterized by weaker union influence. In Slovenia, union influence is, as expected, stronger while influence in Slovakia is similar to that in the Czech Republic. All the results are consistent with other researchers' national findings and remain robust when we control for business cycle and market conditions.

Significantly, the business cycle is negatively correlated with union influence in PSCs: In periods of favorable market conditions influence is low but increases when the business cycle moves unfavorably. Adding a set of industry controls reproduces the results from previous specifications and also suggests important differences across industries. Given aggregate services as a reference category, union influence is stronger in primary industries and manufacturing, while in the construction sector it is similar to services.

Finally, we extend the last specification, considering the association of HRM with union influence and report our results in Table 4a, column 6 , and Table 4b, column 5, for the PSCs and the U.K. samples, respectively. Interestingly, the two HRM scales' coefficients exhibit the same pattern but differ in magnitudes for the two samples as verified by Wald tests, which are significant at $5 \%$ level. For the PSC sample the coefficients of COLL and $C A L C$ are smaller in magnitude, confirming the expectations we have dis- 
Table 5a. Determinants of Union Influence in the PSCs (SUR estimator)

\begin{tabular}{|c|c|c|c|c|c|}
\hline \multirow[b]{2}{*}{ Variables } & \multicolumn{5}{|c|}{ Models } \\
\hline & (1) & (2) & (3) & (4) & (5) \\
\hline Firm size & $\begin{array}{l}0.136^{* * *} \\
(0.013)\end{array}$ & $\begin{array}{l}0.138^{* * *} \\
(0.013)\end{array}$ & $\begin{array}{l}0.126^{* * *} \\
(0.013)\end{array}$ & $\begin{array}{l}0.128 * * * \\
(0.013)\end{array}$ & $\begin{array}{l}0.114 * * * \\
(0.014)\end{array}$ \\
\hline Firm age & $\begin{array}{l}0.080 * * * \\
(0.016)\end{array}$ & $\begin{array}{l}0.067 * * * \\
(0.016)\end{array}$ & $\begin{array}{l}0.049 * * * \\
(0.016)\end{array}$ & $\begin{array}{l}0.045^{* * *} \\
(0.016)\end{array}$ & $\begin{array}{l}0.044^{* * *} \\
(0.016)\end{array}$ \\
\hline Multinational firm & & $\begin{array}{l}-0.140 * * * \\
(0.044)\end{array}$ & $\begin{array}{l}-0.125^{* * * *} \\
(0.042)\end{array}$ & $\begin{array}{l}-0.116^{* * * *} \\
(0.042)\end{array}$ & $\begin{array}{c}-0.131^{* * *} \\
(0.042)\end{array}$ \\
\hline Private firm & & $\begin{array}{l}-0.123 * * * \\
(0.037)\end{array}$ & $\begin{array}{l}-0.138 * * * \\
(0.036)\end{array}$ & $\begin{array}{l}-0.124 * * * \\
(0.036)\end{array}$ & $\begin{array}{l}-0.137 * * * \\
(0.039)\end{array}$ \\
\hline Bulgaria & & & $\begin{array}{l}-0.260^{* * *} \\
(0.065)\end{array}$ & $\begin{array}{l}-0.248^{* * *} \\
(0.064)\end{array}$ & $\begin{array}{l}-0.245^{* * *} \\
(0.064)\end{array}$ \\
\hline Hungary & & & $\begin{array}{l}-0.151^{* *} \\
(0.068)\end{array}$ & $\begin{array}{c}-0.146^{* *} \\
(0.068)\end{array}$ & $\begin{array}{c}-0.136^{* *} \\
(0.067)\end{array}$ \\
\hline Estonia & & & $\begin{array}{l}-0.313^{* * * *} \\
(0.068)\end{array}$ & $\begin{array}{l}-0.307 * * * \\
(0.068)\end{array}$ & $\begin{array}{l}-0.290 * * * \\
(0.067)\end{array}$ \\
\hline Slovenia & & & $\begin{array}{c}0.096 \\
(0.062)\end{array}$ & $\begin{array}{c}0.095 \\
(0.062)\end{array}$ & $\begin{array}{c}0.100 * \\
(0.061)\end{array}$ \\
\hline Slovakia & & & $\begin{array}{c}-0.088 \\
(0.060)\end{array}$ & $\begin{array}{c}-0.083 \\
(0.059)\end{array}$ & $\begin{array}{c}-0.086 \\
(0.059)\end{array}$ \\
\hline Business cycle & & & & $\begin{array}{l}-0.067 * * * \\
(0.022)\end{array}$ & $\begin{array}{l}-0.059 * * * \\
(0.023)\end{array}$ \\
\hline Primary industries & & & & & $\begin{array}{l}0.162 * * * \\
(0.049)\end{array}$ \\
\hline Manufacturing & • & & & & $\begin{array}{l}0.107 * * * \\
(0.036)\end{array}$ \\
\hline Construction & & & & & $\begin{array}{c}0.060 \\
(0.064)\end{array}$ \\
\hline R_squared & 0.23 & 0.30 & 0.46 & 0.47 & 0.51 \\
\hline Number observations & 747 & 747 & 747 & 747 & 747 \\
\hline
\end{tabular}

Notes: Coefficients reported represent marginal effects. Reference country is Czech Republic, and reference industry is Services. Level of significance of estimated coefficients is indicated as follows: $1 \%^{* * *}, 5 \% * *, 10 \% *$.

cussed about the processes and their probable effects on union influence. For the U.K. sample, the pattern is as expected: The coefficient of COLL is positive while the coefficient of $C A L C$ is negative; both are highly statistically significant.

\section{Extensions and Robustness Analysis}

We need to consider the possibility that union influence and HRM practices, as measured by the CALC and COLL scales, are simultaneously determined. We conceive of union influence as arising from interactive, negotiated processes between management and unions. To test and control for simultaneity we specify a system of three equations and estimate it by SURE (seemingly unrelated regression). SURE uses the asymptotically efficient, feasible, GLS algorithm (described in Greene 2003: 340-362) and jointly estimates the three regressions, each with its own error term, as errors are allowed to be correlated. Stepwise expansion of the equation specifications follows the same pattern as in Tables $4 \mathrm{a}$ and $4 \mathrm{~b}$. Estimation results for the union influence equation are reported in Tables $5 \mathrm{a}$ and $5 \mathrm{~b}$ for the PSCs and the U.K. 
Table 5b. Determinants of Union Influence in the United Kingdom (SUR estimator)

\begin{tabular}{lcccc}
\hline & \multicolumn{4}{c}{ Models } \\
\cline { 2 - 5 } Variables & $(1)$ & $(2)$ & $(3)$ & $(4)$ \\
\hline Firm size & $0.102^{* * * *}$ & $0.088^{* * *}$ & $0.088^{* * *}$ & $0.103^{* * * *}$ \\
& $(0.013)$ & $(0.012)$ & $(0.012)$ & $(0.012)$ \\
Firm age & $0.033^{* *}$ & $0.030^{* *}$ & $0.030^{* *}$ & $0.024^{*}$ \\
& $(0.014)$ & $(0.014)$ & $(0.014)$ & $(0.014)$ \\
Multinational firm & & 0.067 & 0.063 & 0.053 \\
& & $(0.046)$ & $(0.046)$ & $(0.045)$ \\
Private firm & $-0.270^{* * *}$ & $-0.282^{* * *}$ & $-0.296^{* * *}$ \\
& & $(0.038)$ & $(0.039)$ & $(0.040)$ \\
Business cycle & & & -0.031 & -0.024 \\
& & & $(0.022)$ & $(0.022)$ \\
Primary industries & & & & $0.225^{* * *}$ \\
& & & & $0.084)$ \\
Manufacturing & & & & $0.252^{* * *}$ \\
Construction & & & & $0.038)$ \\
& & & & 0.074 \\
R_squared & & & $0.085)$ \\
Number observations & 800 & 800 & 800 & 800 \\
\hline
\end{tabular}

Notes: Coefficients reported represent marginal effects. Reference industry is Services. Level of significance of estimated coefficients is: $1 \% * * *, 5 \% * *, 10 \% *$.

samples, respectively, while the (auxiliary) results for the HRM practices' equations are reported in the online version of the paper (Tables A.3a, A.3b, A.4a, and A.4b) on http://eprints.mdx.ac.uk/8038/. Comparing results for the determinants of union influence in the United Kingdom and in the PSCs, the signs of the effects are the same, except for the Multinational firm variable. The main conclusion we draw from Tables $5 \mathrm{a}$ and $5 \mathrm{~b}$ is that the coefficients appear very similar to those reported in Tables $4 \mathrm{a}$ and $4 \mathrm{~b}$, respectively. The fact that the coefficient signs are the same and the magnitudes are very similar suggests that our results are robust. Further, a BreuschPagan test (Breusch and Pagan 1980) of independence (no correlation of residuals) rejects the hypothesis of zero correlation of the residuals and implies that union influence and HRM practices indeed are correlated and likely to be simultaneously determined. ${ }^{5}$

As a further robustness check we estimate SURE regressions with a measure of union presence (TUPR) rather than influence for both samples. Although our main variable of interest is union influence, we consider union presence a necessary condition and the best proxy for influence (Verma et al. 2002; Vernon 2006). Therefore, estimating regressions with TUPR can reveal if there is a gap between (necessary) conditions and realization. The results are reported in Tables $6 \mathrm{a}$ and $6 \mathrm{~b}$ and appear qualitatively similar to the results for union influence reported in Tables $5 \mathrm{a}$ and $5 \mathrm{~b}$. The dependent

\footnotetext{
${ }^{5}$ The Breusch-Pagan Chi-square statistic, a Lagrange Multiplier statistic, rejects the null hypothesis of no correlation in all regressions and is significant at $1 \%$ level or better.
} 
Table $6 a$. Determinants of Union Presence in the PSCs (SUR estimator)

\begin{tabular}{|c|c|c|c|c|c|}
\hline \multirow[b]{2}{*}{ Variables } & \multicolumn{5}{|c|}{ Models } \\
\hline & (1) & (2) & (3) & (4) & (5) \\
\hline Firm size & $\begin{array}{l}0.479 * * * \\
(0.052)\end{array}$ & $\begin{array}{l}0.489 * * * \\
(0.051)\end{array}$ & $\begin{array}{l}0.468^{* * *} \\
(0.050)\end{array}$ & $\begin{array}{l}0.418^{* * * *} \\
(0.050)\end{array}$ & $\begin{array}{l}0.393 * * * \\
(0.050)\end{array}$ \\
\hline Firm age & $\begin{array}{l}0.465^{* * *} \\
(0.063)\end{array}$ & $\begin{array}{l}0.415^{* * * *} \\
(0.063)\end{array}$ & $\begin{array}{l}0.312 * * * \\
(0.059)\end{array}$ & $\begin{array}{l}0.296 * * * \\
(0.059)\end{array}$ & $\begin{array}{l}0.296 * * * \\
(0.058)\end{array}$ \\
\hline Multinational firm & & $\begin{array}{l}-0.473 * * * \\
(0.170)\end{array}$ & $\begin{array}{l}-0.403^{* * *} \\
(0.157)\end{array}$ & $\begin{array}{l}-0.390 * * * \\
(0.157)\end{array}$ & $\begin{array}{l}-0.419 * * * \\
(0.154)\end{array}$ \\
\hline Private firm & & $\begin{array}{l}-0.515 * * * \\
(0.144)\end{array}$ & $\begin{array}{l}-0.559 * * * \\
(0.134)\end{array}$ & $\begin{array}{l}-0.510^{* * *} \\
(0.134)\end{array}$ & $\begin{array}{l}-0.559 * * * \\
(0.142)\end{array}$ \\
\hline Bulgaria & & & $\begin{array}{c}-0.412^{*} \\
(0.242)\end{array}$ & $\begin{array}{l}-0.368 \\
(0.240)\end{array}$ & $\begin{array}{c}-0.347 \\
(0.234)\end{array}$ \\
\hline Hungary & & & $\begin{array}{c}-0.267 \\
(0.248)\end{array}$ & $\begin{array}{c}-0.247 \\
(0.247)\end{array}$ & $\begin{array}{c}-0.198 \\
(0.240)\end{array}$ \\
\hline Estonia & & & $\begin{array}{l}-1.325 * * * \\
(0.246)\end{array}$ & $\begin{array}{l}-1.299 * * * \\
(0.245)\end{array}$ & $\begin{array}{c}-1.206^{* * *} \\
(0.238)\end{array}$ \\
\hline Slovenia & & & $\begin{array}{l}0.974^{* * * *} \\
(0.225)\end{array}$ & $\begin{array}{l}0.975^{* * *} \\
(0.224)\end{array}$ & $\begin{array}{l}1.005^{* * *} \\
(0.219)\end{array}$ \\
\hline Slovakia & & & $\begin{array}{c}-0.100 \\
(0.218)\end{array}$ & $\begin{array}{c}-0.077 \\
(0.216)\end{array}$ & $\begin{array}{c}-0.098 \\
(0.210)\end{array}$ \\
\hline Business cycle & & & & $\begin{array}{c}-0.257^{* * *} \\
(0.083)\end{array}$ & $\begin{array}{l}-0.226 * * * \\
(0.082)\end{array}$ \\
\hline Primary industries & & & & & $\begin{array}{l}0.969 * * * \\
(0.174)\end{array}$ \\
\hline Manufacturing & & & & & $\begin{array}{l}0.577 * * * \\
(0.133)\end{array}$ \\
\hline Construction & & & & & $\begin{array}{c}0.133 \\
(0.242)\end{array}$ \\
\hline R_squared & 0.27 & 0.34 & 0.51 & 0.52 & 0.58 \\
\hline Number observations & 680 & 680 & 680 & 680 & 680 \\
\hline
\end{tabular}

Notes: Coefficients reported represen marginal effects. Reference country is Czech Republic, and reference industry is Services. Level of significance of estimated coefficients is $1 \% * * *$, $5 \% * *, 10 \% *$.

variable, TUPR, is a scale with six categories rather than a dichotomous one, meaning that the coefficients are not directly comparable in terms of magnitudes. ${ }^{6}$ The signs of the estimated coefficients are the same, while the coefficient magnitudes appear proportionately similar. This qualitative similarity indicates that the degree of unions' presence likely approximates their influence.

\section{Discussion and Conclusions}

Our main contribution has been to show the antecedents of union influence at enterprise level in the PSCs. Although both forms of HRM have the expected associations with union influence, these are more muted than in the United Kingdom. Union influence is also associated with high union

${ }^{6}$ The results for the HRM practices equations are reported in the online version of this article (Tables A.5a, A.5b, A.6a, and A.6b) on http://eprints.mdx.ac.uk/8038/ and are quite similar to the SURE results with union influence. 
Table $6 b$. Determinants of Union Presence in the United Kingdom (SUR estimator)

\begin{tabular}{|c|c|c|c|c|}
\hline \multirow[b]{2}{*}{ Variables } & \multicolumn{4}{|c|}{ Models } \\
\hline & (1) & (2) & (3) & (4) \\
\hline Firm size & $\begin{array}{l}0.319 * * * \\
(0.046)\end{array}$ & $\begin{array}{l}0.262 * * * \\
(0.045)\end{array}$ & $\begin{array}{l}0.265^{* * *} * \\
(0.045)\end{array}$ & $\begin{array}{l}0.352 * * * \\
(0.043)\end{array}$ \\
\hline Firm age & $\begin{array}{l}0.130^{* * * *} \\
(0.053)\end{array}$ & $\begin{array}{l}0.135 * * * \\
(0.052)\end{array}$ & $\begin{array}{c}0.130^{* *} \\
(0.052)\end{array}$ & $\begin{array}{c}0.082 * \\
(0.049)\end{array}$ \\
\hline Multinational firm & & $\begin{array}{c}0.210 \\
(0.164)\end{array}$ & $\begin{array}{c}0.189 \\
(0.164)\end{array}$ & $\begin{array}{c}0.086 \\
(0.152)\end{array}$ \\
\hline Private firm & & $\begin{array}{l}-0.908^{* * *} \\
(0.140)\end{array}$ & $\begin{array}{l}-0.915^{* * *} \\
(0.143)\end{array}$ & $\begin{array}{l}-0.960 * * * * \\
(0.140)\end{array}$ \\
\hline Business cycle & & & $\begin{array}{l}-0.072 \\
(0.080)\end{array}$ & $\begin{array}{c}-0.052 \\
(0.075)\end{array}$ \\
\hline Primary industries & & & & $\begin{array}{c}0.710^{* *} \\
(0.298)\end{array}$ \\
\hline Manufacturing & & & & $\begin{array}{l}1.426 * * * \\
(0.132)\end{array}$ \\
\hline Construction & & & & $\begin{array}{c}0.064 \\
(0.310)\end{array}$ \\
\hline R_squared & 0.25 & 0.34 & 0.34 & 0.47 \\
\hline Number observations & 800 & 800 & 800 & 800 \\
\hline
\end{tabular}

Notes: Coefficients reported represent marginal effects. Reference industry is Services. Level of significance of estimated coefficients is $1 \%^{* * *}, 5 \%^{* *}, 10 \% *$.

density, negative movements in the business cycle, and institutional specificities in certain countries. National patterns are broadly anticipated from nation-level studies, but the relationship between national and enterprise influence is not entirely symmetrical.

Our attempts to explain our findings originate in the continued and positive importance of legacy union functions in the PSCs. Unions have certain positive resources: indirect union influence may derive, particularly among older workers, from conceptions of the union as welfare provider, and this may be more relevant than pre-1989 because job security is now hugely reduced. It may also reflect continued identification with the union as an institutional embodiment of the labor collective. Collaborative HRM reflects an approach that is more positive toward institutional forms of employee voice but its effects, which are weaker than in the United Kingdom, may also reflect the historic welfare orientation.

The country results confirm that our outliers in terms of national-level considerations, Slovenia and Estonia, show high and low enterprise-level union influence, respectively, and this reflects common estimates of their national influence. In the national middle range of our sample, union influence in enterprises is similar in both parts of the ex-Czechoslovakia despite Slovakia's relatively highly organized industrial relations (Stockhammer and Onaran 2009), and this suggests the relevance of these countries' shared historic legacy.

Extrapolation from national-level estimates of union influence is not universally valid. The marked weakness of Bulgarian enterprise-level union 
influence is noteworthy. Although consistent with estimates from Global Union Federations' local projects (ICEM/IUF 2009), this weakness is also surprising in view of Thirkell et al.'s (1998) earlier judgment and the modest level of transformation in that economy (Lane 2006).

We find a strong relationship between union influence and membership levels, and this finding supports Verma et al. (2002). Where union density is zero, the result is hardly surprising since no influence can be expected, but influence becomes more common with higher density. This may be interpreted in different ways, and our no-influence finding may be more useful than the influence finding, because it is clearer in its meaning. This constitutes a limitation of our analysis because the latter undifferentiated category may conceal much variation. Conversely, a request for nuanced responses would introduce a major inter-rater reliability problem. Reaching a nuanced and context-sensitive assessment of union influence requires case study work.

Union influence is negatively correlated with the business cycle, especially in the PSCs, and this is consistent with the thesis that union legal watchdog and welfare functions remain significant: Employer and worker demands for these services (especially the former) will likely be higher when enterprises are in difficulty, and this underlines the continuing significance of legal requirements that unions must be consulted on redundancies in some countries (Broughton 2009). The finding is consistent with Bulgarian findings that the onset of redundancy increases levels of union bargaining over its terms (Tomev et al. 2008). Private ownership of all types is also negatively associated with union influence. This suggests that private companies, including MNCs, are establishing employment relationships that tend to reduce union influence. It also implies that union influence in state enterprises is unlikely to survive further privatization and foreign direct investment in these countries.

Overall, our findings lend little support to conceptions of convergence in Europe between East and West. Europe remains in this sense divided. 


\section{Appendix}

Table A.1a. HRM Practices Scales, PSCs

\begin{tabular}{|c|c|c|c|}
\hline \multirow[b]{2}{*}{ Scale/Variable } & \multicolumn{2}{|c|}{ MSP } & \multirow[b]{2}{*}{ Alpha } \\
\hline & Mean & $H$ & \\
\hline Calculative scale (CALC) & & 0.71 & 0.78 \\
\hline Using compulsory redundancies & 0.26 & 0.30 & 0.78 \\
\hline Regular formal appraisal for manual workers & 0.31 & 0.77 & 0.76 \\
\hline Regular formal appraisal for clerical staff & 0.40 & 0.71 & 0.76 \\
\hline Regular formal appraisal for professionals & 0.40 & 0.74 & 0.75 \\
\hline Regular formal appraisal for managers & 0.43 & 0.74 & 0.76 \\
\hline Variable pay based on performance for manual workers & 0.62 & 0.66 & 0.77 \\
\hline Variable pay based on performance for clerical staff & 0.65 & 0.74 & 0.76 \\
\hline Base pay determined at individual level for clerical & 0.68 & 0.81 & 0.77 \\
\hline Base pay determined at individual level for professionals & 0.69 & 0.80 & 0.77 \\
\hline Base pay determined at individual level for manual workers & 0.70 & 0.73 & 0.77 \\
\hline Variable pay based on performance for professionals & 0.70 & 0.74 & 0.76 \\
\hline Formal appraisal used to inform career progress and pay & 0.73 & 0.46 & 0.77 \\
\hline Variable pay based on performance for managers & 0.74 & 0.73 & 0.76 \\
\hline In appraisal no input by the employee & 0.78 & 0.30 & 0.78 \\
\hline Base pay determined at individual level for managers & 0.78 & 0.68 & 0.78 \\
\hline Collaborative scale $(C O L L)$ & & 0.62 & 0.73 \\
\hline Action programme for inclusion of minorities & 0.30 & 0.30 & 0.73 \\
\hline Formal briefings for manual workers & 0.31 & 0.82 & 0.70 \\
\hline Non-managerial career development by project team work & 0.37 & 0.57 & 0.71 \\
\hline Presence of joint consultative committee & 0.44 & 0.30 & 0.73 \\
\hline Formal briefings for clerical staff & 0.46 & 0.72 & 0.70 \\
\hline Managerial career development by project team work & 0.50 & 0.49 & 0.70 \\
\hline Procedure for employees to communicate to managers & 0.54 & 0.48 & 0.71 \\
\hline Strategy for communication to employees & 0.59 & 0.58 & 0.71 \\
\hline Formal briefings for professionals & 0.64 & 0.69 & 0.69 \\
\hline Employee-employer communication by team briefings & 0.69 & 0.55 & 0.70 \\
\hline Employer-employee communication by team briefings & $0.72^{\circ}$ & 0.58 & 0.70 \\
\hline Written mission and corporate values statement & 0.72 & 0.49 & 0.71 \\
\hline Formal briefings for managers & 0.92 & 0.70 & 0.72 \\
\hline
\end{tabular}

Notes: MSP denotes Mokken Scaling Program. H is Loevinger's coefficient of homogeneity (weighted); all $\mathrm{H}$-coefficients are significantly different from zero at the $p=0.001$ level. Alpha is Cronbach's Alpha measure of reliability for the scale; for each item, the Alpha is for the scale minus the item. 
Table A.1b. HRM Practices Scales, United Kingdom

\begin{tabular}{|c|c|c|c|}
\hline \multirow[b]{2}{*}{ Scale/Variable } & \multicolumn{2}{|c|}{$M S P$} & \multirow[b]{2}{*}{ Alpha } \\
\hline & Mean & $H$ & \\
\hline Calculative scale ( $C A L C)$ & & 0.69 & 0.80 \\
\hline In appraisal no input by the employee & 0.14 & 0.30 & 0.79 \\
\hline Using compulsory redundancies & 0.31 & 0.30 & 0.78 \\
\hline Variable pay based on performance for professionals & 0.38 & 0.72 & 0.77 \\
\hline Regular formal appraisal for manual workers & 0.40 & 0.74 & 0.80 \\
\hline Variable pay based on performance for manual workers & 0.44 & 0.64 & 0.79 \\
\hline Variable pay based on performance for clerical staff & 0.47 & 0.71 & 0.78 \\
\hline Variable pay based on performance for managers & 0.48 & 0.69 & 0.78 \\
\hline Regular formal appraisal for clerical staff & 0.60 & 0.79 & 0.78 \\
\hline Regular formal appraisal for professionals & 0.62 & 0.79 & 0.78 \\
\hline Regular formal appraisal for managers & 0.64 & 0.76 & 0.78 \\
\hline Base pay determined at individual level for manual workers & 0.69 & 0.50 & 0.79 \\
\hline Base pay determined at individual level for clerical & 0.75 & 0.66 & 0.78 \\
\hline Base pay determined at individual level for professionals & 0.76 & 0.67 & 0.78 \\
\hline Formal appraisal used to inform career progress and pay & 0.79 & 0.40 & 0.79 \\
\hline Base pay determined at individual level for managers & 0.81 & 0.70 & 0.78 \\
\hline Collaborative scale (COLL) & & 0.60 & 0.71 \\
\hline Non-managerial career development by project team work & 0.27 & 0.67 & 0.71 \\
\hline Action programme for inclusion of minorities & 0.37 & 0.35 & 0.71 \\
\hline Managerial career development by project team work & 0.41 & 0.67 & 0.70 \\
\hline Formal briefings for manual workers & 0.47 & 0.76 & 0.67 \\
\hline Presence of joint consultative committee & 0.55 & 0.35 & 0.70 \\
\hline Procedure for employees to communicate to managers & 0.54 & 0.62 & 0.71 \\
\hline Formal briefings for clerical staff & 0.60 & 0.75 & 0.66 \\
\hline Strategy for communication to employees & 0.73 & 0.62 & 0.69 \\
\hline Formal briefings for professionals & 0.76 & 0.65 & 0.66 \\
\hline Written mission and corporate values statement & 0.84 & 0.31 & 0.69 \\
\hline Employee-employer communication by team briefings & 0.89 & 0.33 & 0.70 \\
\hline Employer-employee communication by team briefings & 0.90 & 0.34 & 0.70 \\
\hline Formal briefings for managers & 0.94 & 0.60 & 0.69 \\
\hline
\end{tabular}

Notes: MSP denotes Mokken Scaling Program. H is Loevinger's coefficient of homogeneity (weighted); all H-coefficients are significantly different from zero at the $p=0.001$ level. Alpha is Cronbach's Alpha measure of reliability for the scale; for each item, the Alpha is for the scale minus the item.

\section{References}

Baranowska, Anna, and Michael Gebel. 2008. Temporary employment in Central and Eastern Europe: Individual risk patterns and temporary employment. University of Mannheim Working Paper 106.

Bernaciak, Magdalena, Anil Duman, and Vera Scepanovic. 2010. Employee welfare and collective bargaining in exposed and protected sectors: Evidence from Poland and Serbia. RECWOWE Publication, Dissemination and Dialogue Centre, Edinburgh: REC-WP 04/ 2010.

Bohle, Dorothee, and Béla Greskovits. 2007. The state, internationalization, and capitalist diversity in Eastern Europe. Competition and Change 11(2): 89-115.

Breusch, Trevor, and Adrian Pagan. 1980. The LM test and its applications to model specification in econometrics. Review of Economic Studies 47: 239-54.

Brewster, Chris, Wolfgang Mayrhofer, and Michael Morley (Eds.). 2005. Human Resource Management in Europe: Evidence of Convergence? Oxford: Elsevier Butterworth-Heinemann.

Broughton, Andrea. 2009. Guidelines on Socially-Sensitive Labour Force Resiructuring in South Eastern Europe. Geneva: International Labour Office. 
Buchen, Clemens. 2007. Estonia and Slovenia as antipodes. In David Lane and Martin Myant

(Eds.), Varieties of Capilalism in Post-Communist Countries, pp. 65-85. London: Palgrave.

Casale, Giuseppe. 1999. Tripartism and industrial relations in Central and Eastern European countries. In Giuseppe Casale (Ed.), Social Dialogue in Central and Eastern Europe, pp. 1-36. Geneva: International Labour Office.

Croucher, Richard. 2010. Employee involvement in Ukraine. International Journal of Human Resource Management 21(14): 2659-76.

Croucher, Richard, and Elizabeth Cotton. 2009. Global Unions, Global Business: Global Union Federations and International Business. London: Middlesex University Press.

Crowley, Stephen. 2004. Explaining labour weakness in post-communist Europe: Historical legacies and comparative perspective. East European Politics and Societies 18(3): 394-429.

Danilovich, Hanna, and Richard Croucher. 2011. Labour management in Belarus: Transcendent retrogression. Communist Siudies and Transition Politics 27(2): 241-62.

Dimitrova, Dimitrina, and Jacques Vilrokx (Eds.). 2005. Trade Union Strategies in Central and Eastern Europe: Towards Decent Work. Geneva and Budapest: International Labour Office.

Drzewiecka, Anna. 2007. The joys and perils of conducting field research in Eastern Europe. European Political Science 6:295-301.

[EFILWC] European Foundation for the Improvement of Living and Working Conditions. 2009. Multinational Companies and Collective Bargaining. Dublin: EFILWC. Online publication accessed at http://eurofound.europa.eu (11 March 2010).

[EIRO] European Industrial Relations Observatory Online. 2010. Country profiles.

Fraile, Lydia (Ed.). 2009. Blunting Neoliberalism: Tripartism and Economic Reforms in the Developing World. Basingstoke: Palgrave Macmillan.

Funk, Lothar, and Hagen Lesch. 2004. Industrial relations in Central and Eastern Europe: Organisational characteristics, co-determination and labour disputes. Intereconomics (September/October): 264-70.

Gennard, John. 2007. Managing membership decline in a hostile environment: The case of the print unions in the Czech Republic, Slovakia and Hungary. European Joumal of Industrial Relations 13(1): 89-108.

Giacobbe-Miller, J., D. Miller, and V. Victorov. 1998. A comparison of Russian and US pay allocation decisions, distributive justice judgements, and productivity under different payment conditions. Personnel Psychology 51:137-63.

Gomez-Mejia, Luis, and Theresa Welbourne. 1994. Compensation strategies in a global context. In Raymond Noe, John Hollenbeck, Barry Gerhart, and Patrick Wright (Eds.), Readings in Human Resource Managemenl, pp. 561-62. Homewood, IL: Irwin Publishing.

Gooderham, Paul, Odd Nordhaug, and K. Ringdal. 1998. When in Rome, do they do as Romans? HRM practices of US subsidiaries in Europe. Management International Review 38:4763.

- 1999. Institutional and rational determinants of organizational practices: Human resource management in European firms. Administrative Science Quarterly 44:507-31.

. 2006. National embeddedness and HRM in US Subsidiaries in Europe and Australia. Human Relations 59(1): 1491-1513.

Gospel, Howard, and Andrew Pendleton. 2005. Corporate governance and labour management: International comparison. In Howard Gospel and Andrew Pendleton (Eds.), Corporate Governance and Labour Management: An International Comparison, pp. 1-32. Oxford: Oxford University Press.

Greene, William. 2003. Econometric Analysis, 5th ed. Upper Saddle River, NJ: Prentice Hall.

Haraszti, Miklós. 1978. A Worker in a Worker's State. Translated by Michael Wright. New York: Universe Books.

ICEM/IUF. 2009. Report no. 14/09: Bulgaria. Document in authors' possession.

[ILO] International Labour Organisation. 2000. World Labour Report: Income Security and Protection in a Changing World. Geneva: International Labour Office.

King, Lawrence P. 2007. Central European capitalism in comparative perspective. In Bob Hancké, Martin Rhodes, and Mark Thatcher (Eds.), Beyond Varieties of Capitalism: Conflict, Contradictions and Complementarities in the European Economy. Oxford: Oxford University Press. Knell, Mark, and Martin Srholec. 2007. Diverging pathways in Central and Eastern Europe. 
In David Lane and Martin Myant (Eds.), Varieties of Capitalism in Post-Communist Countries, pp. 40-44. London: Palgrave.

Konings, Jozef, Marian Rizov, and Hylke Vandenbussche. 2003. Investment and financial constraints in transition economies: Micro evidence from Poland, the Czech Republic, Bulgaria and Romania. Economics Letters 78(2): 253-58.

Kornai, János. 1992. The Socialisı System: The Political Economy of Communism. Princeton, NJ: Princeton University Press.

Lane, David. 2006. Post-state socialism: A diversity of capitalisms? In David Lane and Martin Myant (Eds.), Varieties of Capitalism in Post-Communist Countries, pp. 13-39. London: Palgrave.

Mailand, Mikkel, and Jesper Due. 2004. Social dialogue in Central and Eastern Europe: Present state and future development. European Joumal of Industrial Relations 10(2): 179-98.

Meardi, Guglielmo. 2006. I sindacati nell'Europa postcomunista: attori scomparsi? In Luisa Chiodi and Francesco Privitera (Eds.), Guida ai paesi dell'Europa centrale, orientale e balcanica, pp. 15-24. Bologna: Il Mulino.

2007a. Multinationals in the new EU member states and the revitalisation of trade unions. Debalte: Joumal of Contemporary Central and Easterm Europe 15(2): 177-93.

- 2007b. More voice after more exit? Unstable industrial relations in Central Eastern Europe. Industrial Relations Journal 38(6): 503-23.

Mokken, Robert J., and Charles Lewis. 1982. A nonparametric approach to the analysis of dichotomous item responses. Applied Psychological Measurement 6:417-30.

Noelke, Andreas, and Arjan Vliegenthart. 2009. Enlarging the varieties of capitalism: The emergence of dependent market economies in East Central Europe. World Politics 61:670 702.

Ost, David. 2000. Illusory corporatism in Eastern Europe: Neoliberal tripartism and postcommunist class identities. Politics and Society 28(4): 503-30.

Pollert, Anna. 2005. Gender, transformation and employment in Central Eastern Europe. European Journal of Industrial Relations 11 (2): 213-30.

Psychogios, Alexandros, Leslie Szamosi, and Geoffrey Wood. 2010. Introducing employment relations in South Eastern Europe. Employee Relations 32(3): 205-11.

Rizov, Marian. 2005. Transition and enterprise restructuring: The role of budget constraints and bankruptcy costs. Economics Letlers 86(1): 129-34.

Rizov, Marian, and Richard Croucher. 2009. Human resource management and performance in European firms. Cambridge Journal of Economics 33(2): 253-72.

Sjitsma, Klaas, Pierre Debets, and Ivo Molenaar. 1990. Mokken scale analysis for polytomous items: Theory, a computer program and an empirical application. Quality and Quantity 24:173-88.

Soulsby, Anna, and Ed Clark. 2007. Organisation theory and the post-socialist transformation: Contributions to organisational knowledge. Human Relations 60(10): 1419-42.

Stockhammer, Engelbert, and Ozlem Onaran. 2009. National and sectoral influences on wage determination in Central and Eastern Europe. European Journal of Industrial Relations $15(3): 317-38$.

Storey, John. 2001. Human resource management today: An assessment. In J. Storey (Ed.), Human Resource Management: A Critical Text. London: Thomson Learning.

Thirkell, John, Krastyu Petkov, and Sarah Vickerstaff. 1998. The Transformation of Labour Relations: Restructuring and Privatisation in Eastern Europe and Russia. Oxford: Oxford University Press.

Tomev, Lyuben, Nadezhda Daskalova, Tatiana Mihailova, and Violeta Ivanova. 2008. Wages and collective bargaining in Bulgaria. Soulh East Europe Review 2:219-37.

Trif, Aurora. 2005. Change and continuity in the role of industrial relations actors in Romania: Case study evidence. Centre for International Business paper 2-05.

- 2008. Opportunities and challenges of EU accession: industrial relations in Romania. European Journal of Industrial Relations 14(4): 461-78.

Tung, R. L., and S. J. Havlovic. 1996. Human resource management in transitional economies: The case of Poland and the Czech Republic. International Jourmal of Human Resource Managemen 1 7(1): 1-19. 
Verma, Anil, Tom A. Kochan, and Stephen Wood. 2002. Union decline and prospects for revival. British Journal of Industrial Relations 40(3): 373-84.

Vernon, Guy. 2006. Does density matter: The significance of comparative historical variation in unionization. European Journal of Industrial Relations 12(2): 189-209.

Vos, Kees. 2006. Europeanization and convergence in industrial relations. European Journal of Industrial Relations 12(3): 311-28.

Welz, Christian, and Timo Kauppinen. 2005. Industrial action and conflict resolution in the new member states. European Journal of Industrial Relations 11 (1): 91-106.

[WITW] Wiener Institut für Internationale Wirtschaftsvergleiche. 2003. Annual Database Easterm Europe. Accessed at http://www.wiiw.ac.at (December 2009).

Williams, Colin C. 2010. Beyond the formal/informal jobs divide: Evaluating the presence of hybrid "under-declared" employment in South East Europe. International Journal of Human Resource Management 21(14): 2529-46.

Woolfson, Charles. 2007. Labour standards and migration in the New Europe: Post-Communist legacies and perspectives. European Joumal of Industrial Relations 13(2): 199-218. 
Copyright of Industrial \& Labor Relations Review is the property of Cornell University and its content may not be copied or emailed to multiple sites or posted to a listserv without the copyright holder's express written permission. However, users may print, download, or email articles for individual use. 